\title{
Complexes of the selected transition metal ions with 4-methoxycinnamic acid
}

\section{Physico-chemical properties}

\author{
Wiesława Ferenc • Beata Cristóvão • \\ Jan Sarzyński · Paweł Sadowski
}

Received: 7 July 2011/Accepted: 16 September 2011/Published online: 13 October 2011

(c) The Author(s) 2011. This article is published with open access at Springerlink.com

\begin{abstract}
In this study, 4-methoxycinnamates of Mn(II), $\mathrm{Co}(\mathrm{II}), \mathrm{Ni}(\mathrm{II}), \mathrm{Cu}(\mathrm{II}), \mathrm{Cd}(\mathrm{II}), \mathrm{Nd}(\mathrm{III})$ and $\mathrm{Gd}(\mathrm{III})$ were synthesised. From the infrared (IR) spectra analysis of complexes, sodium salt and according to the spectroscopic criteria the carboxylate groups seem to be bidentate chelating. The complexes of 4-methoxycinnamates lose the water molecules in one or two steps. The final products of their decomposition are oxides of the respective metals. The enthalpy values of dehydration process were determined. The FTIR spectra of the gas phase products indicate that the decomposition of the complexes is connected mainly with the release of molecules of water $\left(\mathrm{H}_{2} \mathrm{O}\right)$, carbon dioxide $\left(\mathrm{CO}_{2}\right)$, carbon monoxide $(\mathrm{CO})$, methane $\left(\mathrm{CH}_{4}\right)$ and other hydrocarbons. The analysed compounds follow the Curie-Weiss law. The magnetic moment values experimentally determined change as follows: from $5.90 \mu_{\mathrm{B}}$ to $6.27 \mu_{\mathrm{B}}$ for $\mathrm{Mn}(\mathrm{II})$ complex, from $4.57 \mu_{\mathrm{B}}$ to $4.99 \mu_{\mathrm{B}}$ for $\mathrm{Co}(\mathrm{II})$ complex, from $3.68 \mu_{\mathrm{B}}$ to $3.30 \mu_{\mathrm{B}}$ for $\mathrm{Ni}(\mathrm{II})$ complex, from $1.87 \mu_{\mathrm{B}}$ to $1.96 \mu_{\mathrm{B}}$ for $\mathrm{Cu}(\mathrm{II})$ complex, from $3.06 \mu_{\mathrm{B}}$ to $3.51 \mu_{\mathrm{B}}$ for $\mathrm{Nd}$ (III) complex, and from $6.91 \mu_{\mathrm{B}}$ to $6.90 \mu_{\mathrm{B}}$ for $\mathrm{Gd}(\mathrm{III})$ complex.
\end{abstract}

W. Ferenc $(\bowtie) \cdot$ B. Cristóvão

Faculty of Chemistry, Maria Curie-Skłodowska University, 20-031 Lublin, Poland

e-mail: wetafer@poczta.umcs.lublin.pl

J. Sarzyński

Institute of Physics, Maria Curie-Skłodowska University, 20-031 Lublin, Poland

P. Sadowski

Department of Inorganic Chemistry, Maria Curie-Skłodowska University, 20-031 Lublin, Poland
Keywords 4-Methoxycinnamates - Thermal stability · Magnetic moments $\cdot \mathrm{Mn}(\mathrm{II}) \cdot \mathrm{Co}(\mathrm{II}) \cdot \mathrm{Ni}(\mathrm{II}) \cdot \mathrm{Cu}(\mathrm{II}) \cdot$ $\mathrm{Nd}(\mathrm{III}) \cdot \mathrm{Gd}(\mathrm{III})$ complexes

\section{Introduction}

Cinnamic acid (3-phenyl-2-propanoic acid) being a derivative of phenylalanine comprises a relatively large family of organic isomers [1]. It has antibacterial, antifungal and antiparasitic properties, and its derivatives are an important pharmaceuticals for high blood pressure and stroke prevention having antitumour activity [2-5]. From the survey of literature, it follows that there are articles that mainly deal with the study of cinnamic acid structure, its properties, derivatives and complexes with alkali metals, such as $\mathrm{Zn}(\mathrm{II}), \mathrm{Hg}(\mathrm{I}), \mathrm{Hg}(\mathrm{II}), \mathrm{Cd}(\mathrm{II})$, and $\mathrm{Zn}$ (II) [2-10]. Having very important biological activity and specific structure, cinnamic acid has been still extensively and solidly studied.

4-Methoxycinnamic acid as derivative of cinnamic acid is used in cosmetology and medicine as antibacterial agent $[11,12]$. Its esters were also applied in the perfumer's industry as essential components of aromatic substance, perfumes and pharmaceuticals [13]. Moreover, they are used for synthetic indigo production as well. 4-Methoxycinnamic acid may be also applied as optical filter or it may deactivate molecules exited by light to protect the polymers and other organic substance [14, 15]. In cosmetics, 4-methoxycinnamates are used for the protection of skin against UV-A and UV-B radiation [16, 17].

In our experiments, the complexes obtained as microcrystalline powder are characterised by elemental analysis, infrared (IR) spectral data, thermal studies and X-ray diffraction measurements. Thermal characterizations allowed 
us to evaluate the assumed position of crystallization water molecules in outer or inner spheres of complex coordination, determine the endo- or exoeffects connected with such processes as dehydration, melting, oxidation, reduction and estimate the strength of bonding between atoms or groups of atoms and ions. The magnetic susceptibility were measured to study the nature of coordination of the central ions and ligands to get information whether the analysed complexes are of low or high spin or if the ligands form the strong or weak fields and if the analysed compounds are monomers or dimers.

\section{Experimental}

\section{Materials}

The complexes of 4-methoxycinnamic acid anion with of $\mathrm{Mn}(\mathrm{II}), \mathrm{Co}(\mathrm{II}), \mathrm{Ni}(\mathrm{II}), \mathrm{Cu}(\mathrm{II}), \mathrm{Cd}(\mathrm{II}), \mathrm{Nd}(\mathrm{III})$ and $\mathrm{Gd}(\mathrm{III})$ were prepared by the addition of the equivalent quantities of $0.1 \mathrm{M}$ ammonium 4-methoxycinnamate $(\mathrm{pH} \sim 5)$ to a hot solution containing the $\mathrm{Mn}(\mathrm{II}), \mathrm{Co}(\mathrm{II}), \mathrm{Ni}(\mathrm{II}), \mathrm{Cu}(\mathrm{II})$, $\mathrm{Cd}(\mathrm{II}), \mathrm{Nd}(\mathrm{III})$ and $\mathrm{Gd}(\mathrm{III})$ chlorides and crystallizing at $20{ }^{\circ} \mathrm{C}$. In order to obtain the $\mathrm{Nd}$ (III) and $\mathrm{Gd}(\mathrm{III})$ chlorides the $\mathrm{Nd}_{2} \mathrm{O}_{3}$ and $\mathrm{Gd}_{2} \mathrm{O}_{3}(99.9 \%$ pure, Aldrich Chemical Company) samples of $0.8 \mathrm{~g}$ was separately digested in the equivalent volumes ( 0.44 and $0.41 \mathrm{~cm}^{3}$, respectively) of concentrated $\mathrm{HCl}\left(35-38 \%\right.$ pure, $d=1.18 \mathrm{~g} / \mathrm{cm}^{3}$, Polish Chemical Reagents in Gliwice (Poland)). The solution was constantly heated. The rare earth(III) chloride was practically evaporated to dryness. The residue was dissolved in water forming the solution of lanthanide(III) chloride, $\mathrm{pH}$ value of which was equal to $\sim 5$. To the hot solutions of chlorides, the equivalent amounts of $0.1 \mathrm{M}$ ammonium 4-methoxycinnamate were added.

4-Methoxycinnamate of ammonium ( $\mathrm{pH} \sim 5$ ) of $0.1 \mathrm{M}$ concentration was prepared by the addition of concentrated solution of $\mathrm{NH}_{3}$ aq (25\% pure, Polish Chemical Reagents in Gliwice (Poland)) to 4-methoxycinnamic acid water solution (99\% pure, Aldrich Chemical Company).

In order to reach the equilibrium state the solids were heated for $1 \mathrm{~h}$ at $50-60{ }^{\circ} \mathrm{C}$ with constant stirring. Next they were filtered off, washed with hot water and methanol to remove ammonium ions and dried at $30{ }^{\circ} \mathrm{C}$ to a constant mass.

The 4-methoxycinnamate of $\mathrm{Na}(\mathrm{I})$ was prepared by the addition of equivalent amount of $0.1 \mathrm{M}$ ammonium 4-methoxycinnamate to $\mathrm{NaOH}$ solution containing $1 \mathrm{~g}$ $\mathrm{NaOH}$ (analytically pure, Polish Chemical Reagents in Gliwice (Poland)).

For the preparation of the complexes, the following chlorides of d-block elements were used: $\mathrm{MnCl}_{2} \cdot 4 \mathrm{H}_{2} \mathrm{O}$, $\mathrm{CoCl}_{2} \cdot 6 \mathrm{H}_{2} \mathrm{O}, \quad \mathrm{NiCl}_{2} \cdot 6 \mathrm{H}_{2} \mathrm{O}, \quad \mathrm{CuCl}_{2} \cdot 2 \mathrm{H}_{2} \mathrm{O}, \quad \mathrm{CdCl}_{2} \cdot 6 \mathrm{H}_{2} \mathrm{O}$ (analytically pure, REAGENTS-Chemical Enterprise in Lublin (Poland)).

\section{Methods}

The contents of carbon and hydrogen were determined by elemental analysis using a CHN 2400 Perkin-Elmer analyser. In order to estimate if analysed complexes were obtained in the pure form without $\mathrm{Cl}(\mathrm{I})$ ions, the Schöniger method for chloride content determination was used. The contents of $\mathrm{M}(\mathrm{II})$ and $\mathrm{M}(\mathrm{III})$ metals were established by means of ED XRF spectrophotometer (Canberra-Packard) (Table 1).

The IR spectra of complexes were recorded over the range of 4,000-400 $\mathrm{cm}^{-1}$ using M-80 spectrophotometer (Carl Zeiss, Jena). Samples for IR spectra measurements were prepared as $\mathrm{KBr}$ discs.

The thermal stability and decomposition of the complexes were studied in air using Setsys 16/18 (Setaram)TG, DTG and DSC instruments. The experiments were carried out two times under air flow in the temperature range of $20-700{ }^{\circ} \mathrm{C}$ at a heating rate of $10{ }^{\circ} \mathrm{C} \mathrm{min}^{-1}$. The initial mass of samples of 4-methoxycinnamates of $\mathrm{Mn}(\mathrm{II}), \mathrm{Co}(\mathrm{II})$, $\mathrm{Ni}(\mathrm{II}), \mathrm{Cu}(\mathrm{II}), \mathrm{Cd}(\mathrm{II}), \mathrm{Nd}(\mathrm{III})$ and $\mathrm{Gd}(\mathrm{III})$ used for measurements were following: $\mathrm{Mn}$ (II), $7.52 \mathrm{mg}$; $\mathrm{Co}(\mathrm{II}), 7.65 \mathrm{mg}$; $\mathrm{Ni}(\mathrm{II}), 7.21 \mathrm{mg}$; $\mathrm{Cu}(\mathrm{II}), 7.29 \mathrm{mg}$; $\mathrm{Cd}(\mathrm{II}), 7.42 \mathrm{mg}$; $\mathrm{Nd}(\mathrm{III})$, $8.64 \mathrm{mg}$; and $\mathrm{Gd}(\mathrm{III}), 7.96 \mathrm{mg}$. Samples of the compounds were heated in $\mathrm{Al}_{2} \mathrm{O}_{3}$ crucibles. The ranges of temperature of complex decompositions were determined by computer program. The TG-FTIR measurements were also made in the nitrogen atmosphere with the use of Q5000 instrument (Firm TA Instruments) with Nicolet 6700 Spectrophotometer. The experiments were carried out in Pt crucibles under

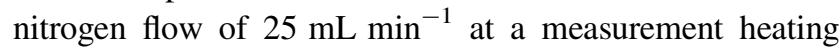
rate of $15^{\circ} \mathrm{C} \mathrm{min}^{-1}$. The masses of samples in experiments were following: $\mathrm{Mn}(\mathrm{II}), 6.321 \mathrm{mg}$; $\mathrm{Co}(\mathrm{II}), 7.079 \mathrm{mg}$; $\mathrm{Ni}(\mathrm{II})$, $3.793 \mathrm{mg} ; \quad \mathrm{Cu}(\mathrm{II}), 5.492 \mathrm{mg} ; \quad \mathrm{Cd}(\mathrm{II}), 4.528 \mathrm{mg} ; \mathrm{Nd}(\mathrm{III})$, $6.401 \mathrm{mg}$; and $\mathrm{Gd}(\mathrm{III}), 5.257 \mathrm{mg}$. The thermal stability for the analysed complexes was also studied in the range of

Table 1 Elemental analysis data of $\mathrm{Mn}(\mathrm{II}), \mathrm{Co}(\mathrm{II}), \mathrm{Ni}(\mathrm{II}), \mathrm{Cu}(\mathrm{II})$, $\mathrm{Cd}(\mathrm{II}), \mathrm{Nd}(\mathrm{III})$ and $\mathrm{Gd}(\mathrm{III})$ 4-methoxycinnamates

\begin{tabular}{|c|c|c|c|c|c|c|}
\hline \multirow{2}{*}{$\begin{array}{l}\text { Complex } \\
\mathrm{L}=\mathrm{C}_{10} \mathrm{H}_{9} \mathrm{O}_{3}\end{array}$} & \multicolumn{2}{|l|}{$\mathrm{C} / \%$} & \multicolumn{2}{|l|}{$\mathrm{H} / \%$} & \multicolumn{2}{|l|}{$\mathrm{M} / \%$} \\
\hline & Calcd. & Found & Calcd. & Found & Calcd. & Found \\
\hline $\mathrm{MnL}_{2} \cdot 2 \mathrm{H}_{2} \mathrm{O}$ & 53.00 & 52.50 & 4.94 & 4.90 & 12.00 & 11.75 \\
\hline $\mathrm{CoL}_{2} \cdot 2 \mathrm{H}_{2} \mathrm{O}$ & 53.46 & 53.01 & 4.90 & 4.67 & 13.12 & 13.20 \\
\hline $\mathrm{NiL}_{2} \cdot \mathrm{H}_{2} \mathrm{O}$ & 55.70 & 54.99 & 4.64 & 4.29 & 13.67 & 13.46 \\
\hline $\mathrm{CuL}_{2} \cdot \mathrm{H}_{2} \mathrm{O}$ & 55.04 & 55.00 & 4.58 & 4.60 & 14.67 & 14.50 \\
\hline $\mathrm{CdL}_{2} \cdot 2 \mathrm{H}_{2} \mathrm{O}$ & 47.00 & 46.90 & 4.38 & 4.07 & 22.31 & 22.00 \\
\hline $\mathrm{NdL}_{3} \cdot \mathrm{H}_{2} \mathrm{O}$ & 51.93 & 51.73 & 4.18 & 3.84 & 20.80 & 20.73 \\
\hline $\mathrm{GdL}_{3} \cdot 2 \mathrm{H}_{2} \mathrm{O}$ & 49.72 & 49.29 & 4.28 & 4.03 & 21.68 & 21.48 \\
\hline
\end{tabular}


$25-250{ }^{\circ} \mathrm{C}$ in the air atmosphere at a heating rate of $5{ }^{\circ} \mathrm{C} \min ^{-1}$. The masses of complexes used for measurements were following: $\mathrm{Mn}(\mathrm{II}), 8.24 \mathrm{mg}$; Co(II), $7.94 \mathrm{mg}$; $\mathrm{Ni}(\mathrm{II}), 6.92 \mathrm{mg} ; \quad \mathrm{Cu}(\mathrm{II}), 7.70 \mathrm{mg} ; \quad \mathrm{Cd}(\mathrm{II}), 8.21 \mathrm{mg}$; $\mathrm{Nd}(\mathrm{III}), 8.07 \mathrm{mg}$; and Gd(III), $7.27 \mathrm{mg}$. Magnetic susceptibilities of polycrystalline samples of 4-methoxycinnamates of $\mathrm{Mn}(\mathrm{II}), \mathrm{Co}(\mathrm{II}), \mathrm{Ni}(\mathrm{II}), \mathrm{Cu}(\mathrm{II}), \mathrm{Cd}(\mathrm{II}), \mathrm{Nd}(\mathrm{III})$ and $\mathrm{Gd}(\mathrm{III})$ were investigated at -196 to $30{ }^{\circ} \mathrm{C}$. The measurements were carried out using the Gouy's method. Weight changes were obtained from Cahn RM-2 electrobalance. The calibrant employed was $\mathrm{Hg}\left[\mathrm{Co}(\mathrm{SCN})_{4}\right]$ for which the magnetic susceptibility was assumed to be $1.644 \times 10^{-5} \mathrm{~cm}^{3} \mathrm{~g}^{-1}$. Correction for diamagnetism of the constituent atoms was calculated by the use of Pascal's constants [18].

\section{Results and discussion}

4-Methoxycinnamates of $\mathrm{Mn}(\mathrm{II}), \mathrm{Co}(\mathrm{II}), \mathrm{Ni}(\mathrm{II}), \mathrm{Cu}(\mathrm{II})$, $\mathrm{Cd}(\mathrm{II}), \mathrm{Nd}(\mathrm{III})$ and $\mathrm{Gd}(\mathrm{III})$ were obtained as polycrystalline solids. The metal ion-to-ligand mole ratio is $1: 2$ and 1:3 in the case for d-electron metal complexes and those of $4 \mathrm{f}$ metal ion ( $\mathrm{Nd}(\mathrm{III})$ and $\mathrm{Gd}(\mathrm{III})$ ) compounds, respectively. Their formulae are $\mathrm{ML}_{2} \cdot n \mathrm{H}_{2} \mathrm{O}$ and $\mathrm{ML}_{3} \cdot n \mathrm{H}_{2} \mathrm{O}$, where $\mathrm{L}=$ $\mathrm{C}_{10} \mathrm{O}_{3} \mathrm{H}_{9}$, and $n=2$ for $\mathrm{M}(\mathrm{II})=\mathrm{Mn}, \mathrm{Co}, \mathrm{Cd}$ and $\mathrm{M}(\mathrm{III})=$ $\mathrm{Gd}$, and $n=1$ for $\mathrm{M}(\mathrm{II})=\mathrm{Ni}, \mathrm{Cu}$ and $\mathrm{M}(\mathrm{III})=\mathrm{Nd}$. Their colours are the following: pale pink for $\mathrm{Mn}(\mathrm{II})$, pink for $\mathrm{Co}(\mathrm{II})$, green for $\mathrm{Ni}(\mathrm{II})$, blue for $\mathrm{Cu}(\mathrm{II})$, yellow for $\mathrm{Cd}(\mathrm{II})$, violet for $\mathrm{Nd}(\mathrm{III})$ and white for $\mathrm{Gd}(\mathrm{III})$.

\section{IR spectra}

The IR spectra of 4-methoxycinnamic acid, 4-methoxycinnamates of $\mathrm{Mn}(\mathrm{II}), \mathrm{Co}(\mathrm{II}), \mathrm{Ni}(\mathrm{II}), \mathrm{Cu}(\mathrm{II}), \mathrm{Cd}(\mathrm{II})$, $\mathrm{Nd}(\mathrm{III}), \mathrm{Gd}(\mathrm{III})$ and for sodium salt were recorded. Their

Table 2 Wavenumbers $\left(\mathrm{cm}^{-1}\right)$ of $\mathrm{COO}^{-}$and $\mathrm{M}-\mathrm{O}$ bands in the analysed complexes of $\mathrm{Mn}(\mathrm{II}), \mathrm{Co}(\mathrm{II}), \mathrm{Ni}(\mathrm{II}), \mathrm{Cu}(\mathrm{II}), \mathrm{Cd}(\mathrm{II}), \mathrm{Nd}(\mathrm{III})$, $\mathrm{Gd}(\mathrm{III})$ and $\mathrm{Na}$ and that of the $\mathrm{COOH}$ band in 4-methoxycinnamic acid

\begin{tabular}{llllll}
\hline $\begin{array}{l}\text { Compound } \\
\mathrm{L}=\mathrm{C}_{10} \mathrm{H}_{9} \mathrm{O}_{3}\end{array}$ & $\mathrm{C}=\mathrm{O}$ & $v_{\text {as }} \mathrm{OCO}$ & $v_{\mathrm{s}} \mathrm{OCO}$ & $\Delta v \mathrm{OCO}$ & $v(\mathrm{M}-\mathrm{O})$ \\
\hline $\mathrm{MnL}_{2} \cdot 2 \mathrm{H}_{2} \mathrm{O}$ & - & 1536 & 1412 & 124 & 520 \\
$\mathrm{CoL}_{2} \cdot 2 \mathrm{H}_{2} \mathrm{O}$ & - & 1536 & 1412 & 124 & 548 \\
$\mathrm{NiL}_{2} \cdot \mathrm{H}_{2} \mathrm{O}$ & - & 1544 & 1408 & 136 & 520 \\
$\mathrm{CuL}_{2} \cdot \mathrm{H}_{2} \mathrm{O}$ & - & 1550 & 1410 & 140 & 520 \\
$\mathrm{CdL}_{2} \cdot 2 \mathrm{H}_{2} \mathrm{O}$ & - & 1532 & 1408 & 124 & 516 \\
$\mathrm{NdL}_{3} \cdot \mathrm{H}_{2} \mathrm{O}$ & - & 1532 & 1400 & 132 & 556 \\
$\mathrm{GdL}_{3} \cdot 2 \mathrm{H}_{2} \mathrm{O}$ & - & 1528 & 1392 & 136 & 560 \\
$\mathrm{NaL}$ & - & 1552 & 1408 & 144 & - \\
$\mathrm{HL}$ & 1688 & - & - & - & - \\
\hline
\end{tabular}

interpretation was made according to the literature [19-31]. Some results of their IR spectra analysis are presented in Table 2 and Fig. 1. The IR spectrum of 4-methoxycinnamic acid shows the following absorption bands: a strong band of $\mathrm{COOH}$ at $1,688 \mathrm{~cm}^{-1}$, the bands assigned to asymmetric and symmetric vibrations of $\mathrm{CH}_{3}$ group at 2,972-2,936 and 2,844-2,820 $\mathrm{cm}^{-1}$, respectively, the

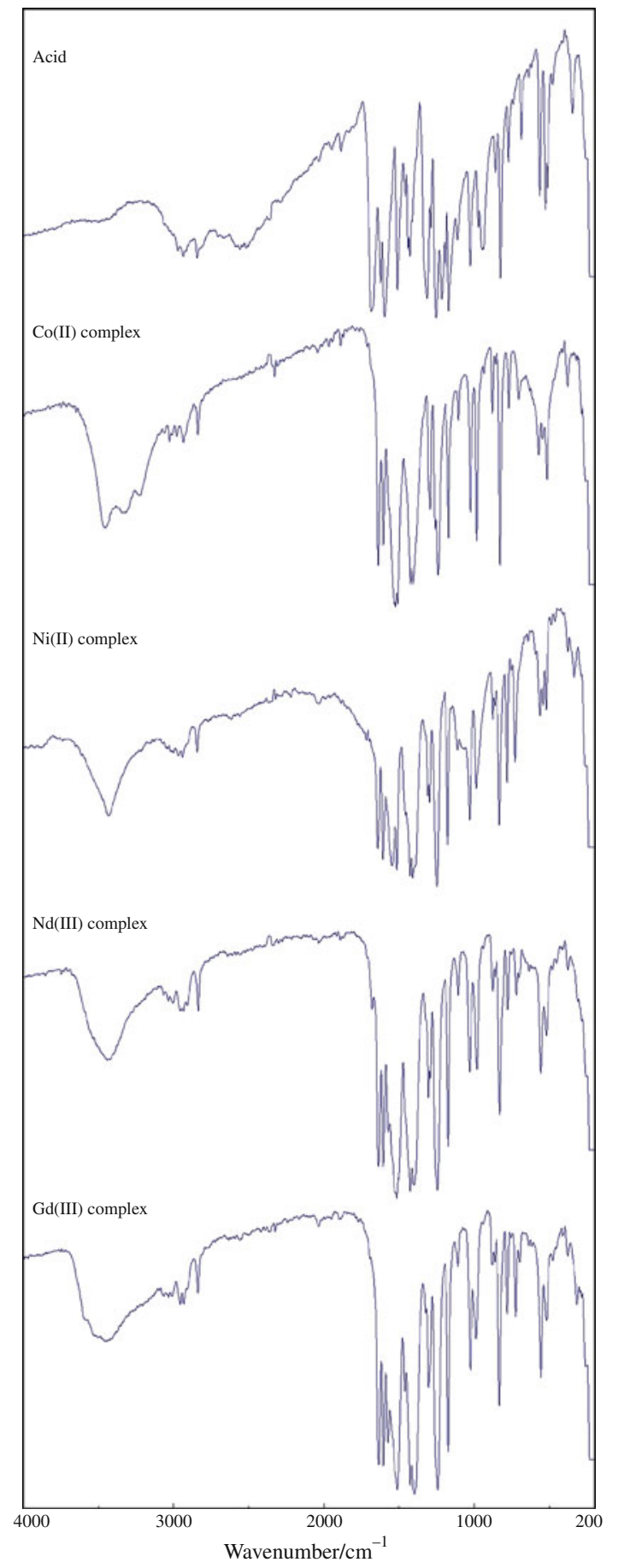

Fig. 1 IR spectra for 4-methoxycinnamic acid and 4-methoxycinnamates of $\mathrm{Co}(\mathrm{II}), \mathrm{Ni}(\mathrm{II}), \mathrm{Nd}(\mathrm{III})$ and $\mathrm{Gd}(\mathrm{III})$ 
bands of $v(\mathrm{C}-\mathrm{C})$ vibrations at 1624, 1596, 1512, 1444 and $1028 \mathrm{~cm}^{-1}$, the bands of $v(\mathrm{C}-\mathrm{H})$ vibrations at $1,288 \mathrm{~cm}^{-1}$, $\beta(\mathrm{C}-\mathrm{H})$ vibration at $1,192 \mathrm{~cm}^{-1}$ and the bands of $-\mathrm{C}-\mathrm{O}-\mathrm{C}-$ at $1,172 \mathrm{~cm}^{-1}$ and $-\mathrm{C}=\mathrm{C}-$ vibrations at $1,428 \mathrm{~cm}^{-1}$, the bands of skeleton vibrations occur at 688 and $568 \mathrm{~cm}^{-1}$. In the IR spectra of 4-methoxycinnamates, the band at $1,688 \mathrm{~cm}^{-1}$ disappears, which confirms that no $\mathrm{COOH}$ is present in the complexes. The intense broad absorption bands at 3,600-3,372 $\mathrm{cm}^{-1}$ indicate the presence of water molecules. The bands arising from asymmetric and symmetric vibrations of $\mathrm{OCO}^{-}$group occur at 1,550-1,528 and $1,412-1,392 \mathrm{~cm}^{-1}$, respectively. The bands at 2,980-2,932 and $2,856-2,836 \mathrm{~cm}^{-1}$ are assigned to asymmetric and symmetric vibrations of $\mathrm{CH}_{3}$ group. The bands at $1,422 \mathrm{~cm}^{-1}$ result from the $-\mathrm{C}=\mathrm{C}-$ vibrations and those at $1,192-1,172 \mathrm{~cm}^{-1}$ are assigned to $-\mathrm{C}-\mathrm{O}-\mathrm{C}-$ vibrations.

The bands at $560-516 \mathrm{~cm}^{-1}$ confirm the metal-oxygen ionic bond. According to literature, these type of bands may be partially coupled with $\mathrm{C}-\mathrm{OCH}_{3}$ banding while those of pure $\mathrm{M}-\mathrm{O}$ stretching vibration may occur also at lower frequencies $[23,27,30]$. It appears that the bands of $\mathrm{M}-\mathrm{O}$ stretching vibrations of $\mathrm{Mn}(\mathrm{II}), \mathrm{Co}(\mathrm{II}), \mathrm{Ni}(\mathrm{II})$ and $\mathrm{Cu}$ (II) complexes may occur in the range of $685-535 \mathrm{~cm}^{-1}$ depending on the structure of complex coordination spheres and kind of ligands [27].

The magnitudes of separation, $\Delta v \mathrm{OCO}$, between the frequencies of $v_{\mathrm{as}} \mathrm{OCO}$ and $v_{\mathrm{s}} \mathrm{OCO}$ in the IR spectra of complexes are lower $\left(\Delta v \mathrm{OCO}=140-124 \mathrm{~cm}^{-1}\right)$ than that in the sodium salt $\left(\Delta v=144 \mathrm{~cm}^{-1}\right)$ which may indicate a smaller degree of ionic bond in the 4-methoxycinnamates of $\mathrm{Mn}(\mathrm{II}), \mathrm{Co}(\mathrm{II}), \mathrm{Ni}(\mathrm{II}), \mathrm{Cu}(\mathrm{II}), \mathrm{Cd}(\mathrm{II}), \mathrm{Nd}(\mathrm{III})$ and $\mathrm{Gd}(\mathrm{III})$ compared to that in the sodium salt. According to the literature, sodium and potassium salt of carboxylic acids are considered to be ionic with their structure and M-O type bonding [30]. Therefore, their IR spectra for unidentate carboxylate group show a large increase in the asymmetric stretching $\mathrm{OCO}^{-}$and a similar decrease in the symmetric stretching $\mathrm{OCO}^{-}$frequencies [27, 29, 30]. The smaller values of $\Delta v \mathrm{OCO}$ for the complex than that for sodium salt indicate the decrease of ionic $\mathrm{M}-\mathrm{O}$ type bonding and the increase of its covalent character [27, 29, 30].

Table 2 shows that in the case of 4-methoxycinnamates of $\mathrm{Mn}(\mathrm{II}), \mathrm{Co}(\mathrm{II})$ and $\mathrm{Cu}(\mathrm{II})$ the bands of $v_{\mathrm{as}} \mathrm{OCO}$ and $v_{\mathrm{s}} \mathrm{OCO}$ are shifted to lower and higher frequencies, respectively, compared to those for the sodium 4-methoxycinnamate $\quad\left(v_{\mathrm{as}} \mathrm{OCO}=1,552 \mathrm{~cm}^{-1}\right.$ and $\quad v_{\mathrm{s}} \mathrm{OCO}=$ $1,408 \mathrm{~cm}^{-1}$ ), while for the complexes of $\mathrm{Nd}(\mathrm{III})$ and Gd(III) they have the lower values of frequencies than those in the sodium salt IR spectrum.

In the case of $\mathrm{Ni}$ (II) and $\mathrm{Cd}$ (II) compounds, the bands of $v_{\text {as }} \mathrm{OCO}$ are removed to lower frequencies, whereas those of $v_{\mathrm{s}} \mathrm{OCO}$ have the same values compared to those in the sodium 4-methoxycinnamate. A general tendency in the relationship between $\Delta v \mathrm{OCO} \quad\left(\Delta v \mathrm{OCO}=v_{\mathrm{as}} \mathrm{OCO}-\right.$ $\left.v_{\mathrm{s}} \mathrm{OCO}\right)$ and the types of coordination of the $\mathrm{OCO}^{-}$group to metal ions by examining the structures and spectral data was observed for a number of acetate salts in the solid state [20, 22]. A general trend in this relationship may be summarised as follows:

(1) Structure of the carboxylate group is bidentate chelating when the bands of $v_{\mathrm{as}} \mathrm{OCO}$ and $v_{\mathrm{s}} \mathrm{OCO}$ in the analysed complex are shifted to lower and higher wavenumbers, compared to those for sodium salt; or $\Delta v \mathrm{OCO}$ of studied complex $\ll \Delta v \mathrm{OCO}$ of sodium salt,

(2) Bidentate bridging structure exists when bands of $v_{\text {as }} \mathrm{OCO}$ and $v_{\mathrm{s}} \mathrm{OCO}$ in studied complex are shifted to higher wavenumbers, compared to those for sodium salt; or $\triangle v \mathrm{OCO}$ of studied complex $\approx \Delta v \mathrm{OCO}$ of sodium salt.

(3) For monodentate geometry of carboxylate group the bands of $v_{\text {as }} \mathrm{OCO}$ and $v_{\mathrm{s}} \mathrm{OCO}$ in the analysed complex are shifted to higher and lower wavenumbers, respectively, compared to those for sodium salt; or $\Delta v \mathrm{OCO}$ of studied complex $\gg \Delta v \mathrm{OCO}$ of sodium salt.

Therefore, according to Nakamoto and Manhas spectroscopic criteria presented above the carboxylate ion in the analysed complexes seems a bidentate chelating ligand probably also in the case of $\mathrm{Cu}(\mathrm{II})$ complex [27, 29, 30]. This conclusion as formulated mainly on the grounds of Nakamoto criterion despite the small difference of $\Delta v \mathrm{OCO}$ for sodium salt $\left(\Delta \nu \mathrm{OCO}=144 \mathrm{~cm}^{-1}\right)$ and analysed $\mathrm{Cu}(\mathrm{II})$ compound $\left(\Delta v \mathrm{OCO}=140 \mathrm{~cm}^{-1}\right)$. Several bands of aromatic system as well as bands which derive from the $-\mathrm{C}=\mathrm{C}-$ double bond are shifted towards the lower wavenumbers in the spectra of complexes compared to the spectrum of acid. These kinds of displacement may be generally interpreted as a decrease in the force constants of bonds which results from a decrease of electronic charge density around atoms [23].

\section{Thermal analysis}

The thermal properties of the 4-methoxycinnamates of $\mathrm{Mn}(\mathrm{II}), \mathrm{Co}(\mathrm{II}), \mathrm{Ni}(\mathrm{II}), \mathrm{Cu}(\mathrm{II}), \mathrm{Cd}(\mathrm{II}), \mathrm{Nd}(\mathrm{III})$ and $\mathrm{Gd}(\mathrm{III})$ were investigated by means of TG, DTG and DSC technique in air in the range of $20-700{ }^{\circ} \mathrm{C}$ and also at $25-250{ }^{\circ} \mathrm{C}$. The ranges of temperature of complex decompositions were determined by computer program. The FTIR spectra of the gas phase products were recorded as well in nitrogen atmosphere.

Their thermal stability was also preliminary investigated by heating their samples in the ceramic crucibles. They were found to decompose with melting process being clearly observed during heating. Some results of the 
Table 3 Temperature range of thermal stability of $\mathrm{Mn}(\mathrm{II}), \mathrm{Co}(\mathrm{II}), \mathrm{Ni}(\mathrm{II}), \mathrm{Cu}(\mathrm{II}), \mathrm{Cd}(\mathrm{II}), \mathrm{Nd}(\mathrm{III})$ and Gd(III) 4-methoxycinnamates in air

\begin{tabular}{|c|c|c|c|c|c|c|c|c|c|c|}
\hline \multirow[t]{2}{*}{$\mathrm{L}=\mathrm{C}_{10} \mathrm{H}_{9} \mathrm{O}_{3}$} & \multirow[t]{2}{*}{$\Delta T_{1} /{ }^{\circ} \mathrm{C}$} & \multicolumn{2}{|c|}{ Mass loss $/ \%$} & \multirow[t]{2}{*}{$n$} & \multirow[t]{2}{*}{$\Delta T_{2} /{ }^{\circ} \mathrm{C}$} & \multicolumn{2}{|c|}{ Mass loss $/ \%$} & \multirow[t]{2}{*}{$\Delta H / \mathrm{kJ} \mathrm{mol}^{-1}$} & \multirow[t]{2}{*}{$T_{\mathrm{k}} /{ }^{\circ} \mathrm{C}$} & \multirow{2}{*}{$\begin{array}{l}\text { Final product } \\
\text { of decomposition }\end{array}$} \\
\hline & & Calcd. & Found & & & Calcd. & Found & & & \\
\hline $\mathrm{MnL}_{2} \cdot 2 \mathrm{H}_{2} \mathrm{O}$ & $116-135$ & 8.00 & 8.16 & 2 & $326-463$ & 83.00 & 82.99 & 86.75 & 467 & $\mathrm{Mn}_{2} \mathrm{O}_{3}$ \\
\hline $\mathrm{CoL}_{2} \cdot 2 \mathrm{H}_{2} \mathrm{O}$ & $105-145$ & 8.01 & 7.92 & 2 & $320-456$ & 80.90 & 81.77 & 97.09 & 462 & $\mathrm{CoO}$ \\
\hline $\mathrm{NiL}_{2} \cdot \mathrm{H}_{2} \mathrm{O}$ & $175-208$ & 4.17 & 4.25 & 1 & $278-417$ & 84.00 & 84.20 & 46.31 & 420 & $\mathrm{NiO}$ \\
\hline $\mathrm{CuL}_{2} \cdot \mathrm{H}_{2} \mathrm{O}$ & $170-207$ & 4.12 & 3.05 & 1 & $281-522$ & 75.00 & 74.50 & 20.27 & 522 & $\mathrm{CuO}$ \\
\hline $\mathrm{CdL}_{2} \cdot 2 \mathrm{H}_{2} \mathrm{O}$ & $100-130$ & 7.17 & 7.10 & 2 & $287-517$ & 74.50 & 74.49 & 89.37 & 520 & $\mathrm{CdO}$ \\
\hline $\mathrm{NdL}_{3} \cdot \mathrm{H}_{2} \mathrm{O}$ & $100-130$ & 2.59 & 2.99 & 1 & $329-540$ & 75.90 & 75.84 & 31.94 & 620 & $\mathrm{Nd}_{2} \mathrm{O}_{3}$ \\
\hline \multirow[t]{2}{*}{$\mathrm{GdL}_{3} \cdot 2 \mathrm{H}_{2} \mathrm{O}$} & 75-106 & 3.72 & 4.18 & 1.5 & $329-529$ & 71.00 & 70.91 & 16.71 & 617 & $\mathrm{Gd}_{2} \mathrm{O}_{3}$ \\
\hline & $106-125$ & 1.24 & 1.30 & 0.5 & & & & 5.57 & & \\
\hline
\end{tabular}

$\Delta T_{1}$ temperature range of dehydration process, $n$ number of water molecules, $\Delta T_{2}$ temperature range of complex decomposition, $\Delta H$ enthalpy value of dehydration process, $T_{\mathrm{k}}$ final temperature of decomposition process
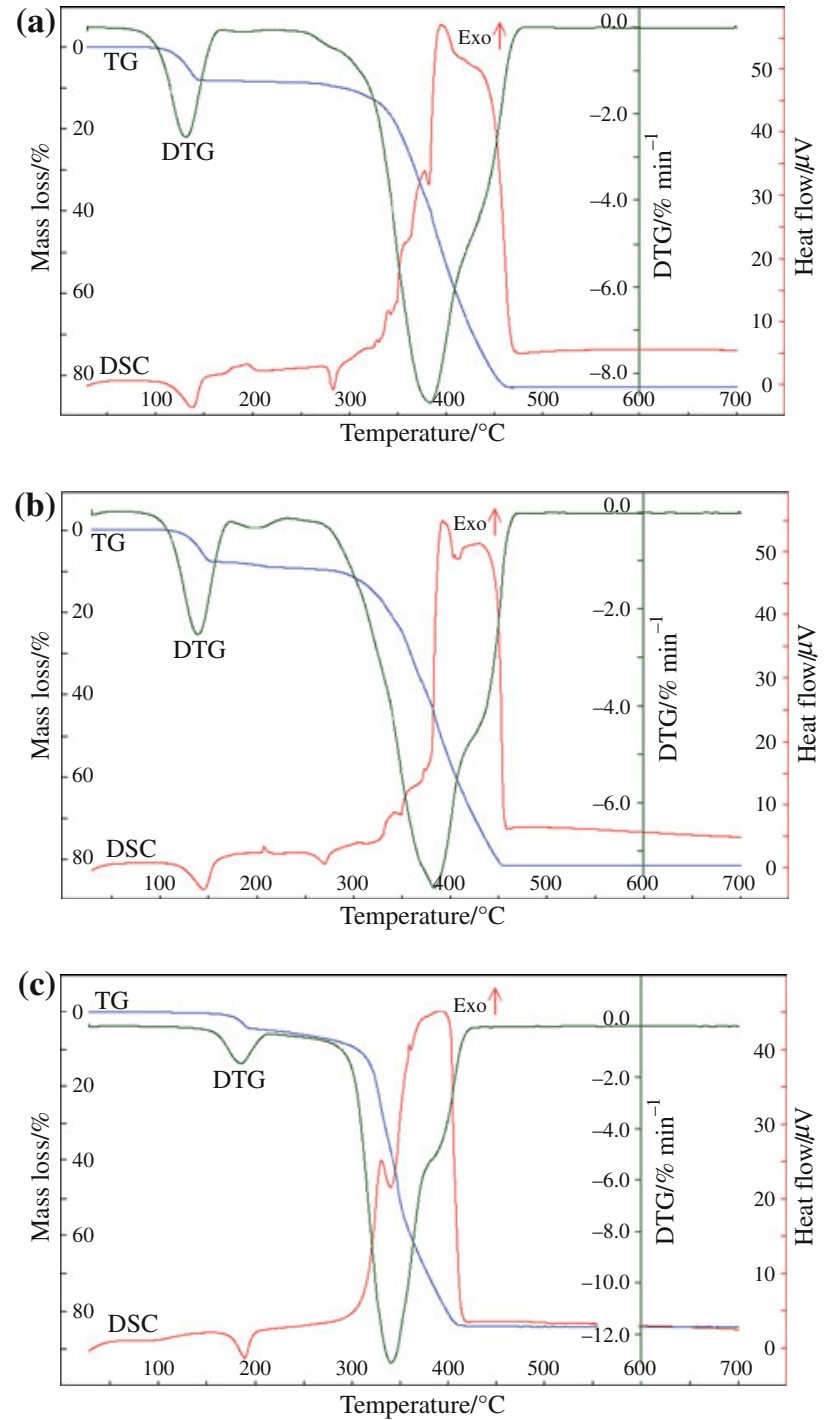

Fig. 2 TG, DTG and DSC curves: a $\mathrm{MnL}_{2} \cdot 2 \mathrm{H}_{2} \mathrm{O} ;$ b $\mathrm{CoL}_{2} \cdot 2 \mathrm{H}_{2} \mathrm{O}$; c $\mathrm{NiL}_{2} \cdot \mathrm{H}_{2} \mathrm{O} ; \mathbf{d ~ N d L} \cdot \mathrm{H}_{2} \mathrm{O}$; e $\mathrm{GdL}_{3} \cdot 2 \mathrm{H}_{2} \mathrm{O}$ in air atmosphere
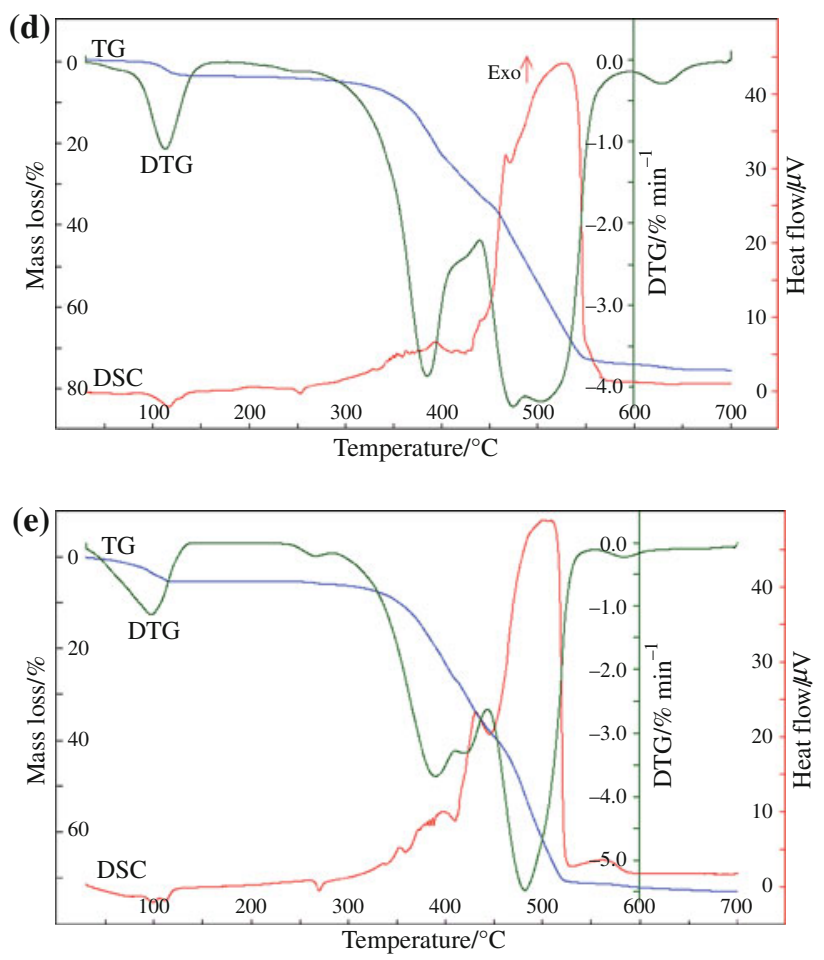

Fig. 2 continued

thermal decomposition of analysed complexes are presented in Table 3 and Figs. 2 and 3 and for their interpretation the literatures $[32,33]$ were used.

For the thermal investigation of $\mathrm{Mn}$ (II) 4-methoxycinnamate, its sample of $7.52 \mathrm{mg}$ was taken. When heated, the complex starts to decompose at $116{ }^{\circ} \mathrm{C}$. It loses in one-step two water molecules in the range of $116-135^{\circ} \mathrm{C}$, which is connected with endothermic process with peak at $128{ }^{\circ} \mathrm{C}$ on DSC curve. The loss of mass found from TG curve is equal to $8.16 \%$ (calcd. $8.00 \%$ ) which corresponds to the 
release of two water molecules (Fig. 2a). The average value of enthalpy for dehydration process of this complex, $\Delta \mathrm{H}$, is equal to $86.75 \mathrm{~kJ} \mathrm{~mol}^{-1}$ and that for one molecule of water $43.37 \mathrm{~kJ} \mathrm{~mol}^{-1}$. In the temperature range of $278-292^{\circ} \mathrm{C}$, the melting process with endothermic peak at $283{ }^{\circ} \mathrm{C}$ (DSC curve) takes place. No loss of mass is observed on TG curve. The complex of Mn(II) in its second step of decomposition eliminates gradually organic ligands in the range of $326-463{ }^{\circ} \mathrm{C}$ with the exothermic effect on DSC curve and ultimately forms the $\mathrm{Mn}_{2} \mathrm{O}_{3}$ at $467{ }^{\circ} \mathrm{C}$. The loss of mass determined from TG curve is equal to $82.99 \%$ while calculated $83.00 \%$ which confirms the $\mathrm{Mn}_{2} \mathrm{O}_{3}$ formation. The final product was identified by comparing its IR spectrum with that of the pure oxide.

The thermal investigation of Co(II) 4-methoxycinnamate was studied with the use of its sample of $7.65 \mathrm{mg}$. On heating the complex also releases two water molecules in one-step $\left(105-145^{\circ} \mathrm{C}\right)$. The dehydration process is accompanied by endothermic effect with peak at $136^{\circ} \mathrm{C}$ (DSC curve). The loss of weight found from TG curve is $7.92 \%$ and calculated as $8.01 \%$. These values confirm the release of two water molecules (Figs. 2b, 3a). The further heating of $\mathrm{Co}$ (II) compound leads to its melting with
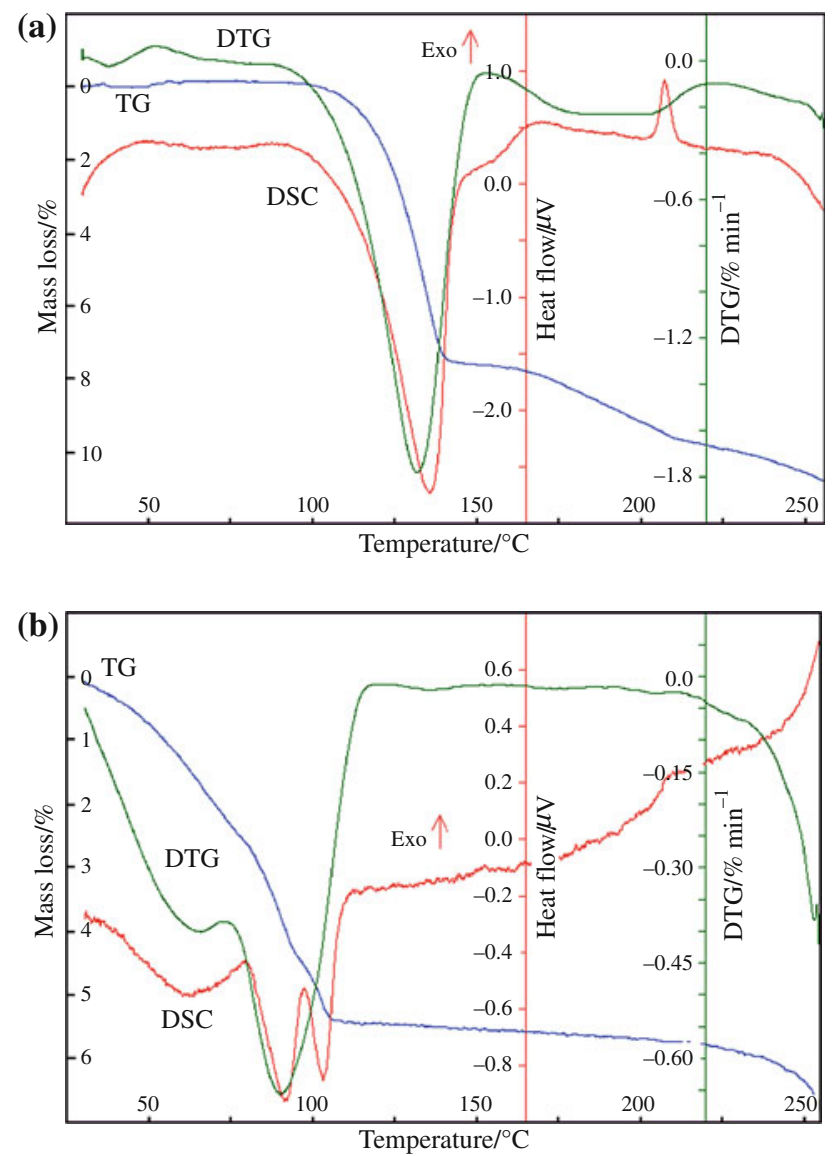

Fig. 3 TG, DTG and DSC curves of the $\mathbf{a} \mathrm{CoL}_{2} \cdot 2 \mathrm{H}_{2} \mathrm{O}$; $\mathbf{b} \mathrm{GdL}_{3} \cdot 2 \mathrm{H}_{2} \mathrm{O}$ in air atmosphere endothermic peak at $267{ }^{\circ} \mathrm{C}$. The TG curve gains the constant level and no mass loss is observed. In the second stage of decomposition 4-methoxycinnamate of $\mathrm{Co}$ (II) gradually releases the organic ligands at $320-456{ }^{\circ} \mathrm{C}$ with strong exothermic effect (DSC curve). The mass loss calculated from TG curve is equal to $81.77 \%$ (theoretical $80.90 \%$ ) indicates the formation of $\mathrm{CoO}$ to be final product of decomposition. It was identified by spectroscopic method. The final temperature of $\mathrm{Co}$ (II) oxide formation is equal to $462{ }^{\circ} \mathrm{C}$. The value of enthalpy determined for dehydration process of $\mathrm{Co}(\mathrm{II})$ is $97.09 \mathrm{~kJ} \mathrm{~mol}^{-1}$ and that for one molecule of water $48.54 \mathrm{~kJ} \mathrm{~mol}^{-1}$.

The 4-methoxycinnamate of $\mathrm{Ni}(\mathrm{II})$ also decomposed in two stages (Fig. 2c). For the measurement, its sample of $7.21 \mathrm{mg}$ was used. In the first step, the dehydration process occurs in the temperature range of $175-208{ }^{\circ} \mathrm{C}$. The experimentally found loss of mass is equal to $4.25 \%$, while the calculated one is $4.17 \%$ which corresponds to release of one water molecule. Next in the second step of $\mathrm{Ni}$ (II) complex decomposition, the organic ligands are eliminated in the range of $278-417^{\circ} \mathrm{C}$, and the final product $\mathrm{NiO}$ is formed $\left(420{ }^{\circ} \mathrm{C}\right)$. The found mass loss is equal to $84.20 \%$, while theoretical one is $84.00 \%$. The average value of dehydration process is equal to $46.31 \mathrm{~kJ} \mathrm{~mol}^{-1}$.

The 4-methoxycinnamate of $\mathrm{Cu}(\mathrm{II})$ is decomposed in two steps. Its sample of $7.29 \mathrm{mg}$ was used for experiment. The first step of thermal decomposition of this complex starts at $170{ }^{\circ} \mathrm{C}$ with the elimination of one water molecule (found $3.05 \%$; calcd. $4.12 \%$ ) and with the endothermic effect with the peak at $187{ }^{\circ} \mathrm{C}$. The average value of enthalpy for this process is $20.27 \mathrm{~kJ} \mathrm{~mol}^{-1}$. In the second step, the $\mathrm{Cu}(\mathrm{II})$ complex releasing partially organic ligands with strong exothermic effect at $281-522{ }^{\circ} \mathrm{C}$ forms ultimately $\mathrm{CuO}$ $\left(522{ }^{\circ} \mathrm{C}\right)$. The calculated loss of mass is equal to $75.00 \%$ and that of found is $74.50 \%$, confirming $\mathrm{CuO}$ formation.

For the thermal analysis of $\mathrm{Cd}$ (II) 4-methoxycinnamate, the sample of $7.42 \mathrm{mg}$ was used. From the obtained data, it was found that it is decomposed in two stages. At first, the dehydration takes place at $100-130{ }^{\circ} \mathrm{C}$ with endothermic peak at $123{ }^{\circ} \mathrm{C}$. The found loss of mass is equal to $7.10 \%$ (calcd. 7.17\%) which corresponds to the removal of two water molecules coordinated to metal ion. Next in the second step of decomposition during further heating, the complex loses the organic ligands with the exothermic effect in the range of $287-517{ }^{\circ} \mathrm{C}$ and forms $\mathrm{CdO}$ (at $520{ }^{\circ} \mathrm{C}$ ) that is the final product of thermal decomposition (found $74.49 \%$; calcd. $74.50 \%$ ). During heating the $\mathrm{Cd}(\mathrm{II})$ complex melts above $258{ }^{\circ} \mathrm{C}$ without mass change on TG curve (endothermic peak at $269^{\circ} \mathrm{C}$ ). The value of enthalpy determined for this complex is equal to $89.37 \mathrm{~kJ} \mathrm{~mol}^{-1}$ and that for one molecule of water is $44.68 \mathrm{~kJ} \mathrm{~mol}^{-1}$.

Figure $2 \mathrm{~d}$ presents the TG and DSC curves of $\mathrm{Nd}(\mathrm{III})$ 4-methoxycinnamate. For the experiment, its sample of 
$8.64 \mathrm{mg}$ was taken. This complex is decomposed in two stages. In the range of $100-130{ }^{\circ} \mathrm{C}$, the $\mathrm{Nd}(\mathrm{III})$ compound releases one water molecule in one step (found $2.99 \%$; calcd. $2.59 \%$ ). The endothermic peak connected with this process occurs at $112{ }^{\circ} \mathrm{C}$ (DSC curve). The value of enthalpy for that dehydration process is equal to $31.94 \mathrm{~kJ} \mathrm{~mol}^{-1}$. The second stage of its decomposition occurs at $329-540{ }^{\circ} \mathrm{C}$ finally with the formation of $\mathrm{Nd}_{2} \mathrm{O}_{3}$ at $620{ }^{\circ} \mathrm{C}$. The found loss of mass is $75.84 \%$ (calcd. $75.90 \%$ ) which corresponds to neodymium(III) oxide formation.

For the thermal decomposition of Gd(III) 4-methoxycinnamate, the sample of $7.96 \mathrm{mg}$ was taken. It decomposes in three steps (Figs. 2e, 3b). Firstly, the molecules of water are removed in two steps in the ranges of 75-106 and 106-125 ${ }^{\circ} \mathrm{C}$ with two endothermic peaks at 105 and $112{ }^{\circ} \mathrm{C}$, respectively. In the first step, 1.5 molecule of water are being released (found $4.18 \%$; calcd. $3.72 \%$ ), while in the second one only 0.5 of its molecule (found $1.30 \%$; calcd. 1.24\%). The values of enthalpy for these two dehydration stages are equal to 16.71 and $5.57 \mathrm{~kJ} \mathrm{~mol}^{-1}$, respectively. During further heating, it melts with the endothermic peak at $270{ }^{\circ} \mathrm{C}$ without mass change on TG curve. Next, the $\mathrm{Gd}(\mathrm{III})$ complex gradually eliminating organic ligands forms $\mathrm{Gd}_{2} \mathrm{O}_{3}$ at $617{ }^{\circ} \mathrm{C}$ (found $70.91 \%$; calcd. $71.00 \%$ ).

The final products of 4-methoxycinnamates of $\mathrm{Mn}(\mathrm{II})$, $\mathrm{Co}(\mathrm{II}), \mathrm{Ni}(\mathrm{II}), \mathrm{Cu}(\mathrm{II}), \mathrm{Cd}(\mathrm{II}), \mathrm{Nd}(\mathrm{III})$ and $\mathrm{Gd}(\mathrm{III})$ were identified by the comparison of their X-ray powder patterns and IR spectra with those of the pure oxides.

The gaseous products released during complex decompositions reveal them to be the molecules of $\mathrm{H}_{2} \mathrm{O}, \mathrm{CO}_{2}$, $\mathrm{CO}, \mathrm{CH}_{4}$ and other hydrocarbons. Their FTIR spectra were recorded. For example, the Figs. 4 and 5 show them for $\mathrm{Co}$ (II) and $\mathrm{Ni}$ (II) 4-methoxycinnamate decompositions. In the FTIR spectra recorded for gaseous products for all the analysed complex decompositions, the bands at 4,000-3,500 and 1,700-1,500 $\mathrm{cm}^{-1}\left(75-208{ }^{\circ} \mathrm{C}\right)$ confirm the presence of $\mathrm{H}_{2} \mathrm{O}$ molecules in the complexes. At higher

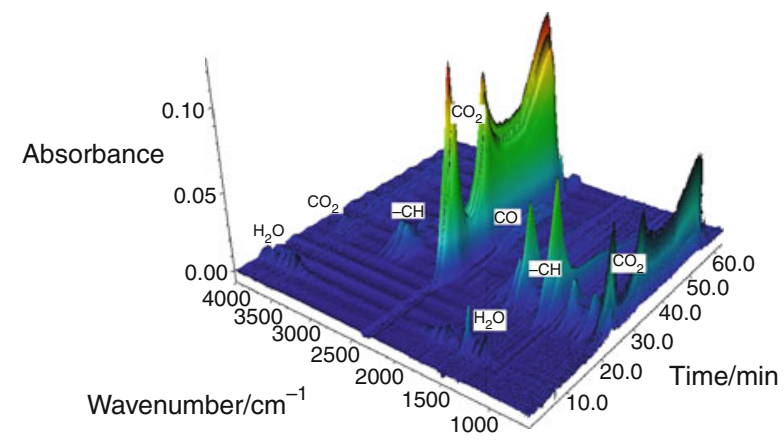

Fig. 4 FTIR spectra of gaseous products for Co(II) 4-methoxycinnamate decomposition in $\mathrm{N}_{2}$ temperature, the bands at 2,250-2,500 and $600-750 \mathrm{~cm}^{-1}$, respectively, result from $\mathrm{CO}_{2}$ vibrations, whereas the bands observed at 2,000-2,200 $\mathrm{cm}^{-1}$ are characteristic peaks of CO. The absorbance peak of methane $\left(\mathrm{CH}_{4}\right)$ appears around $3,000 \mathrm{~cm}^{-1}[34,35]$.

From the survey of literature on the structure and thermal properties of carboxylates of $\mathrm{d}$ - and $4 \mathrm{f}$-electron elements containing water molecules, it is possible to state that analysed compounds form aquacomplexes because the water molecules are coordinated to the central ions [36-38].

\section{Magnetic properties}

The magnetic susceptibility of the 4-methoxycinnamates of $\mathrm{Mn}(\mathrm{II}), \mathrm{Co}(\mathrm{II}), \mathrm{Ni}(\mathrm{II}), \mathrm{Cu}(\mathrm{II}), \mathrm{Cd}(\mathrm{II}), \mathrm{Nd}(\mathrm{III})$ and $\mathrm{Gd}(\mathrm{III})$ was measured in the temperature range of -196 to $30{ }^{\circ} \mathrm{C}$. The complexes of analysed elements follow the CurieWeiss law, since the values of the magnetic susceptibility decrease with increasing temperature. The paramagnetic dependences of magnetic susceptibility values of the complexes as a function of temperatures are presented in Table 4. The effective magnetic moment values were calculated from the equation:

$\mu_{\mathrm{eff}}=2.83\left(\chi_{\mathrm{M}} \cdot T\right)^{1 / 2}$

where $\mu_{\text {eff }}$ is effective magnetic moment, $\chi_{\mathbf{M}}$ is magnetic susceptibility per molecule and $T$ is absolute temperature

The values of the Weiss constant, $\theta$, for all complexes were found to have a negative sign which probably arises from antiferromagnetic spin interaction or from a crystal field splitting of the paramagnetic spin state. This important statement was precisely described in the following literature [39-44]. The magnetic moment data are very close to the spin only values for the respective ions calculated from the equation $\mu_{\text {eff }}=[4 s(s+1)]^{1 / 2}$ in the absence of the magnetic interactions for present spin-system. The magnetic moment values experimentally determined at $-196-30{ }^{\circ} \mathrm{C}$ for $\mathrm{Mn}(\mathrm{II}), \mathrm{Co}(\mathrm{II}), \mathrm{Ni}(\mathrm{II})$, $\mathrm{Cu}(\mathrm{II}), \mathrm{Nd}(\mathrm{III})$ and $\mathrm{Gd}(\mathrm{III})$ are given in Table 4. Their

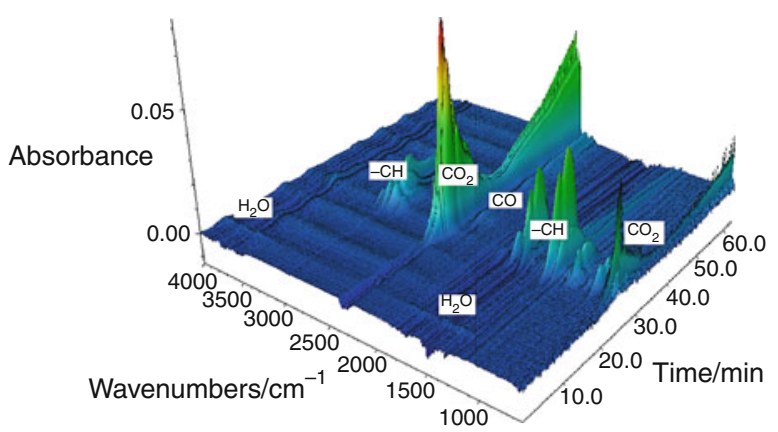

Fig. 5 FTIR spectra of gaseous products for Nd(III) 4-methoxycinnamate decomposition in $\mathrm{N}_{2}$ 


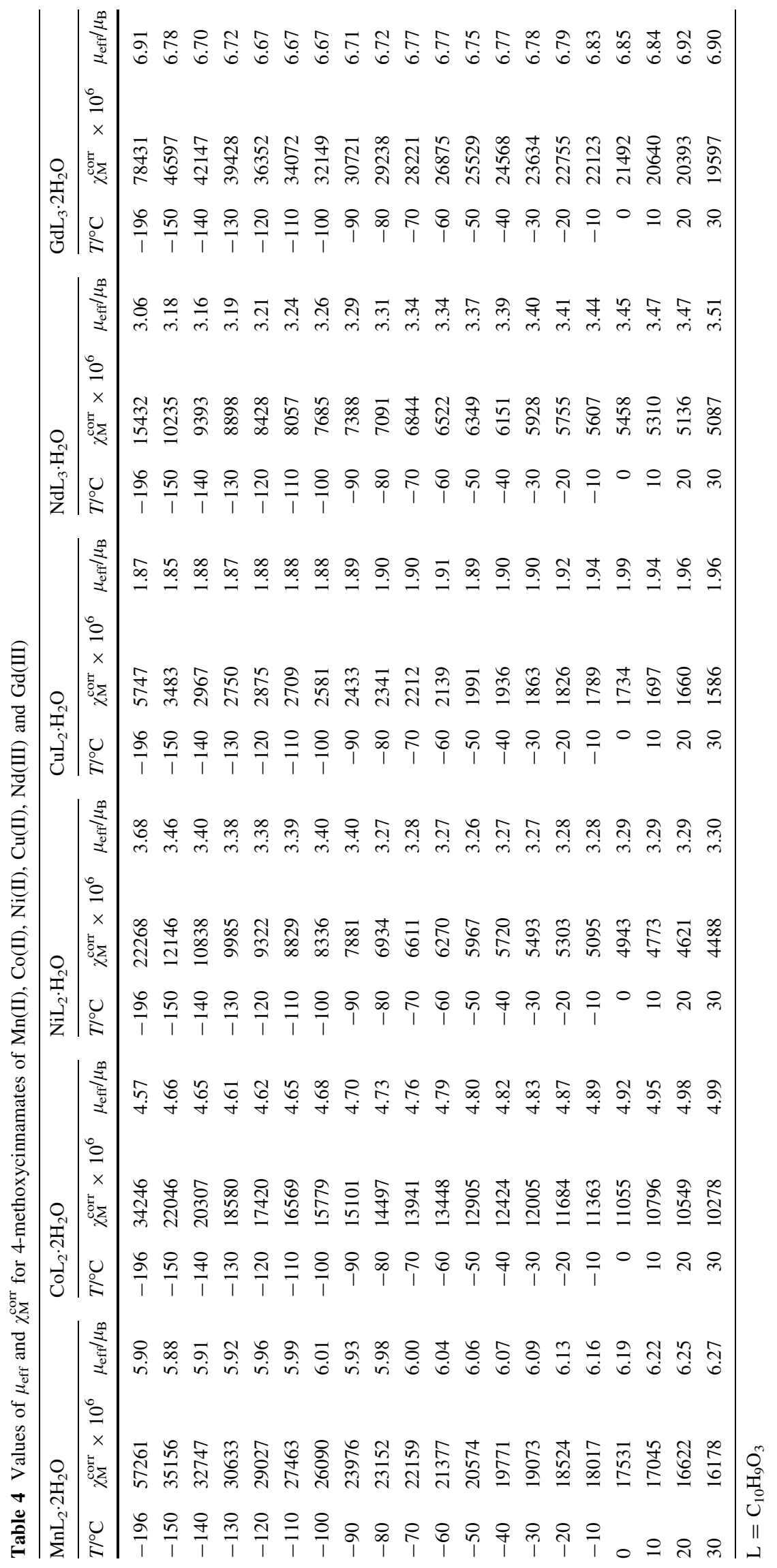


values calculated at room temperature for $\mathrm{Mn}(\mathrm{II}), \mathrm{Co}(\mathrm{II})$, $\mathrm{Ni}(\mathrm{II}), \mathrm{Cu}(\mathrm{II}), \mathrm{Nd}(\mathrm{II})$ and $\mathrm{Gd}(\mathrm{III})$ ions are equal to $5.90 \mu_{\mathrm{B}}$, $3.88 \mu_{\mathrm{B}}, 2.83 \mu_{\mathrm{B}}, 1.73 \mu_{\mathrm{B}}, 3.74 \mu_{\mathrm{B}}$ and $7.23 \mu_{\mathrm{B}}$, respectively [39, 41]. For $\mathrm{Mn}(\mathrm{II}), \mathrm{Co}(\mathrm{II}), \mathrm{Ni}(\mathrm{II})$ and $\mathrm{Cu}(\mathrm{II})$ ions in analysed complexes the magnetic moment values are higher than the spin-only worth because they result from a spin-orbital coupling. The values of $\mu_{\mathrm{eff}}=5.90-6.27 \mu_{\mathrm{B}}$ obtained for $\mathrm{Mn}(\mathrm{II})$ 4-methoxycinnamate suggest that it is high-spin compound with coordination number equals to 6 . In the coordination sphere of $\mathrm{Mn}(\mathrm{II})$ ion there are probably two water molecules and two bidentate anions of 4-methoxycinnamic acid [6,9]. This was confirmed by the IR spectral analysis from which it appears that the carboxylate groups are bidentate. The magnetic moments values of Co(II) 4-methoxycinnamate change from 4.57-4.99 $\mu_{\mathrm{B}}$. They confirm that it is also a high-spin complex with octahedral structure containing two molecules of water and two bidentate carboxylate groups in the coordination sphere of $\mathrm{Co}$ (II). Such character of carboxylate group was also confirmed by the IR spectral analysis as well (Table 2). In the case of $\mathrm{Ni}$ (II) 4-methoxycinnamate the magnetic moment values of complex change from $3.68 \mu_{\mathrm{B}}$ to $3.30 \mu_{\mathrm{B}}$ indicating that the $\mathrm{Ni}(\mathrm{II})$ ion exists in an octahedral triplet ground state with one molecule of water and two bidentate carboxylate groups coordinated to it. The IR spectrum reveals that the carboxylate groups in this compound are in fact bidentate. However, the coordination number of $\mathrm{Ni}$ (II) ion seems to be 5 . The experimental data suggest that the compounds of $\mathrm{Mn}(\mathrm{II}), \mathrm{Co}(\mathrm{II})$ and $\mathrm{Ni}(\mathrm{II})$ are high-spin complexes with the weak ligand fields. In the octahedral coordination of $\mathrm{Mn}$ (II) ion there are four oxygen atoms of two carboxylate groups and two oxygen atoms of water molecules. The coordination numbers of $\mathrm{Mn}(\mathrm{II})$, $\mathrm{Co}(\mathrm{II}), \mathrm{Ni}(\mathrm{II}), \mathrm{Cu}(\mathrm{II}), \mathrm{Nd}(\mathrm{III})$ and $\mathrm{Gd}(\mathrm{III})$ ions could be established on the basis of the complete crystal structure determination of monocrystals but they have not been obtained. Not having full detailed data we may only consider the water molecule positions in analysed complexes $[6,9,32,33]$. The magnetic susceptibility of $\mathrm{Cu}(\mathrm{II}) \mathrm{com}-$ plex changes with rising temperature according to the Curie-Weiss law and the observed effective moment at $-196{ }^{\circ} \mathrm{C}$ is $1.87 \mu_{\mathrm{B}}$ while that at room temperature is $1.96 \mu_{\mathrm{B}}$. Copper in +2 oxidation state has only the spin magnetic moment of $1.73 \mu_{\mathrm{B}}$ but owing to spin orbit coupling, its higher values are often observed [39-44]. The results of $\mu_{\text {eff }}$ obtained for the $\mathrm{Cu}$ (II) complexes may also suggest its to be monomeric with the bidentate chelating carboxylate anion. The experimentally determined room temperature magnetic moment per $\mathrm{Cu}$ (II) in the analysed complex is similar to those observed for other monomeric $\mathrm{Cu}(\mathrm{II})$ compounds and is higher than the $\mathrm{d}^{9}$ spin-only magnetic moment $\mu_{\text {eff }}=1.73 \mu_{\mathrm{B}}$. This discrepancy is explained by the fact that spin-orbital coupling in the ion can mix the ground state representing no orbital momentum, with higher levels of identical multiplicity. The participation of those higher levels results from a small orbital contribution in those cases where it is no to be expected. It may also indicate the operation of ferromagnetic interaction. The complex of Cd(II) is diamagnetic. In the case of $\mathrm{Nd}(\mathrm{III})$ and $\mathrm{Gd}(\mathrm{III})$ 4-methoxycinnamates the paramagnetic central ions remain practically unaffected by diamagnetic ligands coordinated around them. The f-electrons are outside influences and they do not participate in the formation of $\mathrm{M}-\mathrm{O}$ bond. Their energy levels are the same as in the free ions. For $\mathrm{Nd}(\mathrm{IIII})$ and $\mathrm{Gd}(\mathrm{III})$ the ground state is separated by several hundred of $\mathrm{cm}^{-1}$ from the next higher lying state. Therefore the magnetic properties can be taken as those of the ground state alone. Taking into account this fact the $\mathrm{Nd}(\mathrm{III})$ and $\mathrm{Gd}(\mathrm{III})$ ions in analysed compounds act in the same way as the free ions. The values of $\mu_{\text {eff }}$ determined for $\mathrm{Nd}(\mathrm{III})$ and $\mathrm{Gd}(\mathrm{III})$ 4-methoxycinnamates are close to those calculated for them by Hund and Van Vleck [39]. Their values at room temperature for analysed complexes are: $3.47 \mu_{\mathrm{B}}$ for $\mathrm{Nd}$ (III) and $6.92 \mu_{\mathrm{B}}$ for $\mathrm{Gd}(\mathrm{III})$. From values of magnetic moments determined for these complexes it appears that the energies of $4 \mathrm{f}$ electrons in the central ions are not changed compared to those in the free lanthanide ions. Thus, the colours of the complexes stay the same as those in the free lanthanide ions. The electron density in the molecules makes the $\mathrm{f}-\mathrm{f}$ electronic transitions of the central ions to be those of the lowest energy and the absorption occurs at relatively high wavelengths. The $4 \mathrm{f}$ orbitals of $\mathrm{Nd}(\mathrm{III})$ and $\mathrm{Gd}(\mathrm{III})$ ions effectively shielded by the $5 s^{2} 5 p^{6}$ octet. Therefore the metal ligand bonding in analysed lanthanide complexes is mainly electrostatic in nature $[43,44]$.

\section{Conclusions}

4-Methoxycinnamates of $\mathrm{Mn}(\mathrm{II}), \mathrm{Co}(\mathrm{II}), \mathrm{Ni}(\mathrm{II}), \mathrm{Cu}(\mathrm{II})$, $\mathrm{Cd}(\mathrm{II}), \mathrm{Nd}(\mathrm{III})$ and $\mathrm{Gd}(\mathrm{III})$ were found to be complexes containing one or two water molecules. They are stable up to $75-175^{\circ} \mathrm{C}$. Next they lose molecules of water in one or two steps. The losses of mass calculated from TG curves are equal to $1.30-8.16 \%$ (the theoretical values $1.24-8.01 \%$ ). The complex of $\mathrm{Ni}$ (II) is the most thermally stable compound since its initial temperature of dehydration is equal to $175{ }^{\circ} \mathrm{C}$, while $\mathrm{Gd}(\mathrm{III})$ compound has the least thermal stability $\left(75^{\circ} \mathrm{C}\right)$. After the loss of water molecules the complexes of $\mathrm{Mn}(\mathrm{II}), \mathrm{Co}(\mathrm{II}), \mathrm{Ni}(\mathrm{II}), \mathrm{Cu}(\mathrm{II}), \mathrm{Cd}(\mathrm{II}), \mathrm{Nd}(\mathrm{III})$ and $\mathrm{Gd}(\mathrm{III})$ in air are stable up to $278-329{ }^{\circ} \mathrm{C}$ and next they decompose to the respective oxides: $\mathrm{Mn}_{2} \mathrm{O}_{3}, \mathrm{CoO}, \mathrm{NiO}$, $\mathrm{CuO}, \mathrm{CdO}, \mathrm{Nd}_{2} \mathrm{O}_{3}$ and $\mathrm{Gd}_{2} \mathrm{O}_{3}$. The gaseous products of complex decompositions were mainly identified as: $\mathrm{H}_{2} \mathrm{O}$, $\mathrm{CO}_{2}, \mathrm{CO}, \mathrm{CH}_{4}$ and hydrocarbons. The magnetic properties 
of the analysed compounds were studied, and they proved the compunds to be paramagnetic substances that obey Curie-Weiss law.

Open Access This article is distributed under the terms of the Creative Commons Attribution Noncommercial License which permits any noncommercial use, distribution, and reproduction in any medium, provided the original author(s) and source are credited.

\section{References}

1. Madhurambal G, Ravindran B, Mariappan M, Mojumdar SC. Thermal, UV and FTIR spectral studies in alkali metal. J Therm Anal Calorim. 2010;100:811-5.

2. Abdelmoty I, Buchholz V, Di L, Guo C, Kowitz K, Enkelmann $\mathrm{V}$, Wegner G, Foxman BM. Polymorphism of cinnamic and $\alpha$ truxillic acids. Cryst Growth Des. 2005;5:2210-7.

3. Fernandes MA, Levendis DC, Koning CB. Solvate and polymorphs of ortho-ethoxy-trans-cinnamic acid: the crystal and molecular structures. Cryst Eng. 2001;4:215-31.

4. Ahn S, Harris KDM, Kariuki BM, Zin DMS. Polymorphic phase transformation in the 3-bromo-trans-cinnamic acid system. J Solid State Chem. 2001;10:156-61.

5. Kalinowska M, Świsłocka R, Lewandowski W. The spectroscopic (FT-IR, FT-Raman and H, C NMR) and theoretical studies of cinnamic acid and alkali metal cinnamates. J Mol Struct. 2007;8:572-80.

6. Hosomi H, Ohba S, Ito Y. cis-Diaquabis(trans-cinnamato-O, $\left.\mathrm{O}^{\prime}\right)$ zinc(II). Acta Crystallogr C Cryst Struct Commun. 2000;56:e123.

7. Ray PC. Second-order polarizability of $p$-substituted cinnamic acids. Chem Phys Lett. 1996;248:27-30.

8. Fernandes MA, Levendis DC, Schoening FRL. A new polymorph of ortho-ethoxy-trans-cinnamic acid: single-to-single-crystal phase transformation and mechanism. Acta Cryst B Struct Sci. 2004;B60:300-14.

9. Kalinowska M, Swisłocka R, Lewandowski W. Zn(II), Cd(II) and $\mathrm{Hg}(\mathrm{I})$ complexes of cinnamic acid: FT-IR, FT-Raman, ${ }^{1} \mathrm{H}$ and ${ }^{13}$ C NMR studies. J Mol Struct. 2011. doi:10.1016/j.molstruc. 2011.01.063.

10. Ravindran B, Madhurambal G, Mariappan M, Ramamurthi K, Mojumdar SC. Growth and characterization of mercury cinnamate single crystal. J Therm Anal Calorim. 2011. doi:10.1007/ s.10973-011-1292-4.

11. Scheuer E, Warshaw E. Sunscreen allergy: a review of epidemiology, clinical characteristics, and responsible allergens. Dermatitis. 2006;17:3-11.

12. Wolski T, Pszczoła D, Baj T. Budleja Davida (Buddleja davidii Franch)—ozdobna roślina lecznicza o wielokierunkowym działaniu leczniczym. Postępy Fitoterapii. 2010;2:75-82.

13. Singh TS, Mitra S. Interaction of cinnamic acid derivatives with serum albumins: a fluorescence spectroscopic study. Spectrochim Acta A. 2011;78:942-8.

14. Svoboda A, Walterova D, Vostalova J. Ultraviolet light induced alternation to the skin. Biomed Pap Med Fac Univ Palaczy Olomouc Czechoslov Repub. 2006;150:25-38.

15. Salvador A, Chisvert A. Analytical survey on UV filters determination. Anal Chim Acta. 2005;537:1-14.

16. Levy SB. Sunscreens and photoprotection. http://www.emedicine. com (available on-line June 2011).

17. Klimowicz A, Bielecka-Grzela S, Czuba E, Żejmo M. Sunscreens-chemical structure and application. Ann Acad Med Stetin. 2007:53:11-5.

18. Figgis BN, Nyholm RS. A convenient solid for calibration of the Gouy magnetic susceptibility apparatus. J Chem Soc. 1958;4190-1.
19. Silverstein RM, Bassler GC, Morrill TC. Spectrometric identification of organic compounds. New York: Wiley; 1991.

20. Lewandowski W, Barańska H. Comparison of the influence of silver, iron(III) and chromium(III) on the aromatic system of benzoic and salicylic acids in hydrated and anhydrous complexes. Vib Spectrosc. 1991;2:211-20.

21. Köse DA, Necefoğlu H. Synthesis and characterization of bis(nicotinamide) m-hydroxybenzoate complexes of $\mathrm{Co}(\mathrm{II}), \mathrm{Ni}(\mathrm{II})$, $\mathrm{Cu}(\mathrm{II})$ and $\mathrm{Zn}$ (II). J Therm Anal Calorim. 2008;93:509-14.

22. Lewandowski W. Effect of lanthanides on the aromatic system of benzoic acid. Warsaw: Publications of Warsaw Agricultural University, SGGW-AR; 1986. p. 9-45.

23. Burger K. Coordination chemistry: experimental methods. Budapest: Akadèmiai Kiadó; 1973.

24. Bellamy LJ. The infrared spectra of complex molecules. London: Chapman and Hall Ltd; 1975.

25. Varsányi G. Assignments for vibrational spectra of 700 benzene derivatives. Budapest: Akademiai Kiadó; 1973.

26. Gaber M, Rehab AF, Badr-Eldeen DF. Spectral and thermal studies of new $\mathrm{Co}(\mathrm{II})$ and $\mathrm{Ni}$ (II) hexaaza and octaaza macrocyclic complexes. J Therm Anal Calorim. 2008;91:957-62.

27. Nakamoto K. Infrared and Raman spectra of inorganic and coordination compounds. Toronto: Wiley; 1997. p. 1-256.

28. Bridson AK. Inorganic spectroscopic methods. New York: Oxford University Press; 1998. p. 1-30.

29. Manhas BS, Trikha AK. Relationship between the direction of shifts in the carbon-oxygen stretching frequencies of carboxylato complexes and the type of carboxylate coordination. J Indian Chem Soc. 1982;59:315.

30. Mehrotra RC, Bohra R. Metal carboxylates. London: Academic Press; 1983. pp. 8-15, 48-121, 256-322.

31. Cross A, Jones AR. An introduction to practical infrared spectroscopy. London: Butterworths; 1969. p. 1-95.

32. Nikolaev AV, Logvinienko VA, Myachina LI. Thermal analysis. New York: Academic Press; 1969.

33. Paulik F. Special trends in thermal analysis. Chichester: Wiley; 1995. p. 3-98.

34. Xu T, Huang X. Study on combustion mechanism of asphalt binder by using TG-FTIR technique. Fuel. 2010;89:2185-90.

35. Tao L, Zhao G-B, Qian J, Qin Y-K. TG-FTIR characterization of pyrolysis of waste mixtures of paint and tar slag. J Hazard Mater. 2010;175:754-61.

36. Rzączyńska Z, Bartyzel A, Olszewska E, Sawka-Dobrowolska W. Synthesis and characterization of $\mathrm{Co}(\mathrm{II}), \mathrm{Cu}(\mathrm{II})$ and $\mathrm{Zn}(\mathrm{II})$ complexes with 1,2-cyclobutanedicarboxylic acid. Polyhedron. 2006;25:687-94.

37. Rzączyńska Z, Bartyzel A, Głowiak T. Synthesis and characterization of triaquabis (1,1-cyclobutadienedicarboxylato-O, $\mathrm{O}^{\prime}, \mathrm{O}^{\prime \prime}$, $\mathrm{O}^{\prime \prime \prime}$ )dimanganese(II). Polyhedron. 2003;22:2595-9.

38. Stępniak K, Ferenc W, Cristóvão B, Lis T. Crystal structures of 5-chloro-2-methoxybenzoates of $\mathrm{Mn}(\mathrm{II}), \mathrm{Co}(\mathrm{II}), \mathrm{Ni}(\mathrm{II})$ and Zn(II). Ecl Quim. 2007;32:23-8.

39. Van Vleck JH. The theory of electronic and magnetic susceptibilities. Oxford: Oxford University Press; 1932. p. 239-41.

40. Kettle SFA. Physical inorganic chemistry: a coordination chemistry approach. Oxford: Oxford University Press; 2000.

41. Earnshaw A. Introduction to magnetochemistry. New York: Academic Press; 1968. p. 1-83.

42. Figgis BN, Lewis J. Progress in inorganic chemistry. New York: Interscience; 1964.

43. Sinha SP. Systematic and properties of the lanthanides. Dordrecht: Reidel Publishing Company; 1983. p. 7-125.

44. O'Connor I. Progress in inorganic chemistry. New York: Wiley; 1982. p. 203-76. 